\title{
Effects of Feed Supplementation on Nesfatin-1, Insulin, Glucagon, Leptin, T3, Cortisol, and BCS in Milking Ewes Grazing on Semi-Natural Pastures
}

\author{
Olimpia Barbato ${ }^{1,+} \oplus$, Elena De Felice ${ }^{2, *},+\mathbb{D}$, Luca Todini ${ }^{2}$, Laura Menchetti ${ }^{3} \mathbb{D}$, Alessandro Malfatti ${ }^{2, *}$ and \\ Paola Scocco ${ }^{2}$ (1) \\ 1 Department of Veterinary Medicine, University of Perugia, via San Costanzo 4, 06126 Perugia, Italy; \\ olimpia.barbato@unipg.it \\ 2 School of Biosciences and Veterinary Medicine, University of Camerino, via Gentile III da Varano, \\ 62032 Camerino, Italy; luca.todini@unicam.it (L.T.); paola.scocco@unicam.it (P.S.) \\ 3 Department of Agricultural and Food Science, University of Bologna, viale G. Fanin 44, 40137 Bologna, Italy \\ laura.menchetti7@gmail.com \\ * Correspondence: elena.defelice@unicam.it (E.D.F.); alessandro.malfatti@unicam.it (A.M.) \\ + Olimpia Barbato and Elena De Felice shared first co-autorship.
}

check for updates

Citation: Barbato, O.; De Felice, E.; Todini, L.; Menchetti, L.; Malfatti, A.; Scocco, P. Effects of Feed Supplementation on Nesfatin-1, Insulin, Glucagon, Leptin, T3, Cortisol, and BCS in Milking Ewes Grazing on Semi-Natural Pastures. Animals 2021, 11, 682. https:// doi.org/10.3390/ani11030682

Academic Editor: Mariangela Caroprese

Received: 3 February 2021

Accepted: 28 February 2021

Published: 4 March 2021

Publisher's Note: MDPI stays neutral with regard to jurisdictional claims in published maps and institutional affiliations.

Copyright: (c) 2021 by the authors. Licensee MDPI, Basel, Switzerland. This article is an open access article distributed under the terms and conditions of the Creative Commons Attribution (CC BY) license (https:/ / creativecommons.org/licenses/by/ $4.0 /)$.
Simple Summary: In Central Italy Apennine sheep represent the most bred species, which is still bred today in a semi-extensive manner, exploiting the natural pastures. However, the increase in summer aridity induces a decrease in the pastoral value of the grasslands, resulting in poor animal performance and production. Only research-derived innovation can support farmers' economy in order to maintain the pastoral activities. The objective of this study was to evaluate the effects of cereals supplementation on body condition score and metabolic hormones profile in milking ewes grazing on semi-natural pastures on mid mountain rangelands. Our findings showed that feed supplementation preserves grazing ewes from the usual lowering of the body state associated to the lactation period and sustains the metabolic status of animals. Taken together, our results could represent a helpful instrument in the farm management practices.

Abstract: This study aimed to investigate the effects of feed supplementation on body condition score (BCS) and different metabolic hormones concentration in lactating sheep reared in Italian Central Apennine pastures during the grazing summer period. In this study, 24 Comisana $x$ Appenninica pluriparous ewes from June until August were divided into two homogenous groups: the control group (UNS) was free to graze, while the other group (SUP), in addition to grazing, was supplemented with $600 \mathrm{~g} /$ day/head of cereals. At the start of the supplementation and at an interval of 9-10 days until the end of experimentation, BCS evaluation and blood withdrawal to assay nesfatin- 1 , insulin, glucagon, leptin, triiodothyronine and cortisol levels were performed. Univariable analysis showed no remarkable differences between the groups, while multivariable analysis suggested that the UNS group was characterized by a lower BCS and greater nesfatin-1 than the SUP group. These findings can be considered in relation to milk production, which shows a clear better persistence in the SUP group. Our results indicate that nutritional supplementation has protected ewes from the usual lowering of the body state linked to lactation and provides a good maintenance of milk production, determining also a better overall body and metabolic state of the animals, which is important at the beginning of the sexual season.

Keywords: feed supplementation; Ovis aries; metabolic hormones; BCS; drought stress; Italian Central Apennine

\section{Introduction}

It is well known how the feeding strategies and the state of nutrition are fundamental to improve productions in the livestock species. In the sub-Mediterranean areas, drought 
stress, due to the increasing summer aridity, is progressively decreasing the pastoral value of natural and semi-natural pastures used as a trophic resource for ovine semi-extensive breeding, thus negatively reflecting on animal status [1-3]. This fact could be taken into account in the management of flocks reared in Apennine pastures during the springearly autumn period, in which global warming is causing an advance of both the pasture flowering peak and the pasture dryness [4,5].

A better nutrition status can improve the productive and reproductive efficiency through numerous factors, including the circulation of hormones as well as nutrientsensitive metabolites [6]. It has been stamped that endocrine and neuroendocrine events play a fundamental role in regulating food intake and energy homeostasis. As a consequence of the absorption of nutrients and/or changed metabolism, the blood concentration of metabolic hormones can be changed. Furthermore, the process of digestion can induce changes in different hormones due to mechanical or chemical stimulation of receptors in the digestive tract.

Unlike other metabolic hormones, nesfatin (NES1) was identified only relatively recently, and there is still poor knowledge about its role in metabolism in ruminant animals. It was recognized in 2006 as a potent anorexigenic peptide involved in the regulation of homeostatic feeding [7]. Subsequently, its widespread central and peripheral distribution gave rise to additional effects. In fact, NES1 exerts pleiotropic actions at the levels of digestive systems [8], energy and glucose homeostasis [9]. Moreover, it is involved in stress response [10], sleep [11] and reproduction [12,13] in both humans and different animal species.

Pancreatic insulin (INS) is a main endocrine signal in the control of nutrient partitioning and the metabolism of carbohydrates, proteins and lipids. It has a role in homeorhetic processes, which allow the animal to adapt the nutrient partitioning to changes of physiological states and nutrient requirements [14]. In lactating dairy goats, plasma INS levels were positively correlated with energy intake and negatively with dry matter intake [15]. In lactating dairy cows, insulin positively regulates plasma leptin [16].

Glucagon, the other major pancreatic hormone, plays a key role in glucose homeostasis due to its stimulating effect on hepatic glucose output in response to low blood glucose levels [17]. Glucagon has also been suggested to stimulate lipolysis in adipose tissue [18] and to provide a satiety signal [19].

Leptin (LEP), the hormone mainly produced by the adipose tissue, regulates food intake and energy expenditure [20]. Leptin expression and secretion are correlated with body condition, physiological status (puberty, pregnancy, lactation), age, and level of nutrition [21,22]. Furthermore, the presence of leptin receptors at the mammary level [23] suggests a potential role in stimulating mammary development and functions.

The appropriate thyroid gland function is considered crucial to sustain the productive performance in domestic animals (growth, milk, or hair fiber production). Variations of thyroid hormones bioactivity allow animals to adapt their metabolic balance to different environmental conditions, changes in nutrient requirements and availability, and to homeorhetic changes during different physiological stages [24].

The main functions of adrenal cortisol (COR) are to induce protein and fat catabolism, supporting gluconeogenesis. COR makes available body reserves inducing hyperglycemia and providing energy during the stress response. In the current context of climate changes, heat stress can involve animals also in Mediterranean areas, during the summer hotter months, when dairy small ruminants are lactating and nutrient supplies are not always optimal. The effect of heat and nutritional stress on COR secretion is well documented in sheep [25].

The body condition score (BCS) is a more sensitive indicator of the nutritional status of the animals than body weight, which carries also the contribution of the gastrointestinal contents and can lead to an incorrect estimation (over- or under-) of the animal status and welfare [26]. 
Therefore, our study was undertaken to investigate the effects of feed supplementation during the second phase of lactation on body condition and different metabolic hormones blood concentration in lactating sheep reared in the Italian Central Apennine pastures during the summer late spring-early autumn grazing period.

In addition, to our knowledge, until now, there are no studies relating to nutritional status and nesfatin plasma concentration in sheep. Findings resulting from our research could have some future benefits, such as improving the evaluation of the opportunity to design the most appropriate diets or if a supplementation strategy can be considered an appropriate investment by the breeders.

\section{Materials and Methods}

\subsection{Location, Animals, and Diets}

The trial was carried out on 24 Comisana $\times$ Appenninica pluriparous ewes. Lactating ewes were free to graze from the beginning of June to the end of August on a semi-natural pasture located in Central Appennine (Monte Cavallo, altitude $1280 \mathrm{~m}$ a.s.l.; longitude $12^{\circ} 58^{\prime} 53^{\prime \prime}$ Est; latitude $42^{\circ} 59^{\prime} 55^{\prime \prime}$ Nord, Marche region, Italy). The animals at the moment of the offspring separation (near $40 \mathrm{~d}$ post-partum) were divided in two homogeneous groups as far as body weight (BW) and body condition score (BCS), milk yield, parity, and days of lactation (see Supplementary material). One group (SUP, $\mathrm{n}=12$, mean BW $49.4 \pm 6.1$, mean BCS $2.31 \pm 0.3$ ) was supplemented with $600 \mathrm{~g} /$ day/animal of corn and barley (1:1), while the other group (control unsupplemented group, UNS, $n=12$, mean BW $50.5 \pm 5.1$, mean BCS $2.27 \pm 0.3$ ) was fed only with the pasture (Figure S1). The feed supplementation was administered during the morning milking when each animal was in its milking post. The feed supplementation was chosen taking into account the management habits of the farmer and in order to avoid too expensive actions.

The food intake of grazing animals was evaluated by the pasture phytomass removal estimation [27].

Milk production was monitored at three different times: at the beginning (7 July 2016, near 75 days after parturitions, morning milking mean yield $297 \pm 63 \mathrm{~mL}$ by UNS and $306 \pm 64 \mathrm{~mL}$ by SUP ewes), in the middle (21 July 2016, $134 \pm 47 \mathrm{~mL}$ by UNS and $240 \pm 52 \mathrm{~mL}$ by SUP ewes), and in the end (9 August 2016, $125 \pm 51 \mathrm{~mL}$ by UNS and $192 \pm 52 \mathrm{~mL}$ by SUP ewes) of the period of nutritional supplementation as previously described [28].

\subsection{BCS, Blood Collection, and Assays}

Hormone levels and BCS were evaluated before the supplementation on 7 July (T0), and they were then measured every 9-10 days until 22 August (T1-T5) (Figure S1). The last date corresponded to the pre-mating period, when males were introduced in the flock and all females were dried. BCS was evaluated on the basis of a specific sheep method previously described [2-29]. Briefly, BCS is a comprehensive assessment of animal's body status based on muscle/fat relative proportions, and it is considered a useful management tool in determining the welfare of domestic animals. The steps in ovine BCS evaluation are palpation of body structures (processes of the thoracic and lumbar vertebrae), the state of the dorso-medial area, and the general status of animals. Each step, which was done by 3-5 trained valuators, receives a score (0-5) [2], and the mean of the scores for the four parameters constitutes the BCS value. Blood samples were withdrawn by jugular venipuncture in evacuated tubes containing K3-EDTA as anticoagulant (Sarsted, Numbrecht, Germany). Tubes were immediately centrifuged (2500× $g$ for $15 \mathrm{~min}$ ), and the plasma aliquots were stored at $-20^{\circ} \mathrm{C}$ until assayed. The samplings were carried out in all the dates at 7:00-8:00 a.m.

All hormone concentrations were determined as the average of duplicate determinants. To minimize the systematic error owing to inter-assay variability, all samples of each animal were analyzed for each hormone within the same assay session, in which an equal number of animals belonging to the two groups was present. 
Enzyme immunoassays (EIA) were performed using the automated processor Brio 2 reader (Seac, Firenze, Italy). NES1 was assayed on T0, T2, T4 and T5, due to the lack of plasma amount on the other dates. NES1 level was measured using EIA kits (E-E-H2373, Biotechnology Inc., Human NES1, Wuhan, China). The intra-and inter-assay coefficients of variation (CV) were $9.4 \%$ and $11.6 \%$, respectively. Sensitivity (DL) indicated by the manufacturer is $9.38 \mathrm{pg} / \mathrm{mL}$. Plasma INS was determined using the Sheep Insulin ELISA kit (EIA-4739, DRG, Marburg, Germany) and the intra- and inter-assay CVs were $4.3 \%$ and $9.7 \%$, respectively. Sensitivity (DL) indicated by the manufacturer is $0.49 \mu \mathrm{LU} / \mathrm{mL}$. Radioimmunoassay was used to measure plasma glucagon (Glucagon RIA Kit, RB310, Euro Diagnostica AB, Lundavagen, Malmo, Sweden). The intra- and inter-assay coefficients of variation for control samples were $7.6 \%$ and $5.4 \%$, respectively. Sensitivity (DL) indicated by the manufacturer is $3 \mathrm{pmol} / \mathrm{L}$. Plasma LEP concentrations were measured by the multi-species Leptin RIA kit (XL-85K, EMD Millipore Co., Billerica, MA, USA) and the intra- and inter-assay coefficients of variation were 3.4 and $8.7 \%$, respectively. Sensitivity (DL) indicated by the manufacturer is $0.801 \mathrm{ng} / \mathrm{mL}$ Human Equivalent (HE). Total concentrations of 3-3'-5-triiodothyronine $(\mathrm{TH})$ in plasma were assayed using a radioimmunoassay kit (Immunotech, Prague, Czech Republic, IM 3287). Intra- and inter-assay coefficients of variation (CVs) were $6.1 \%$ and $7.8 \%$, respectively. Sensitivity (Detection Limit DL) indicated by the manufacturer is $0.26 \mathrm{nmol} / \mathrm{L}$. Plasma cortisol concentrations were determined using commercial RIA kits (Immunotech, Prague, Czech Republic, IM 1841) and the intraand inter-assay CVs were $7.3 \%$ and $9.1 \%$, respectively. Sensitivity (DL) indicated by the manufacturer is $5 \mathrm{nM} / \mathrm{L}$.

\subsection{Statistical Analysis}

Diagnostic graphics and Shapiro-Wilk were used for testing assumptions and outliers. Since non-normality of the data was detected, insulin was log transformed, while NES1 was categorized into two levels using the median [30], as its distribution did not improve after transformation.

First, the effect of time and supplementation were analyzed for each hormone (except for NES1) and BCS (treated as a continuous variable) by using univariable approaches and Linear Mixed Models (LMMs) procedures. Animals and days were included as random and repeated factors, respectively. The LMMs evaluated the main effects of Group (2 levels: UNS and SUP), Time (6 levels: T0-T5), and the interaction between Group and Time. Sidak adjustment was used for carrying out multiple comparisons. Results were expressed as estimated marginal means \pm standard error (SE) while raw data were presented in figures as means \pm SE.

After categorization, NES1 was analysed by a Generalized Linear Model (GLM) using binomial as the probability distribution and logit as the link function. The effects of group (2 levels: UNS and SUP), sampling time (6 levels: T0-T5), and their interaction were evaluated. Data were presented as percentages, medians (Mdn), and interquartile ranges (IQR).

Finally, a multivariable approach was used by Discriminant Analysis (DA) to find the combinations of variables (BCS and hormones) that distinguish sheep that received supplementation (SUP) from the control group (UNS). The relative importance of each variable on this discrimination was expressed by the Wilks' lambda (the smaller the Wilks' lambda, the more important the variable to the Df) and by the discriminant loadings (correlations between each independent variable and the discriminant scores associated with the Df) [31,32]. Mahalanobis distance was used to identify the presence of multivariate outliers. The performance of the DA was evaluated by leave-one-out cross-validation, calculating the probability for each sample to be accurately classified in the correct group. The centroids (mean discriminant scores of the groups) were used to establish the cutting point for classifying samples during the cross-validation.

Statistical analyses were performed with SPSS Statistics version 25 (IBM, SPSS Inc., Chicago, IL, USA). Statistical significance occurred when $p<0.05$. 


\section{Results}

\subsection{Univariable Approach}

Only the time effect was found for BCS, which was significantly reduced at T4 compared to $\mathrm{T} 0$ (from $1.7 \pm 0.1$ at $\mathrm{T} 0$ to $1.5 \pm 0.1$ at $\mathrm{T} 4 ; p<0.001$ ) (Figure 1 ) and then returned to basal values $\mathrm{T} 5(1.8 \pm 0.1)$.

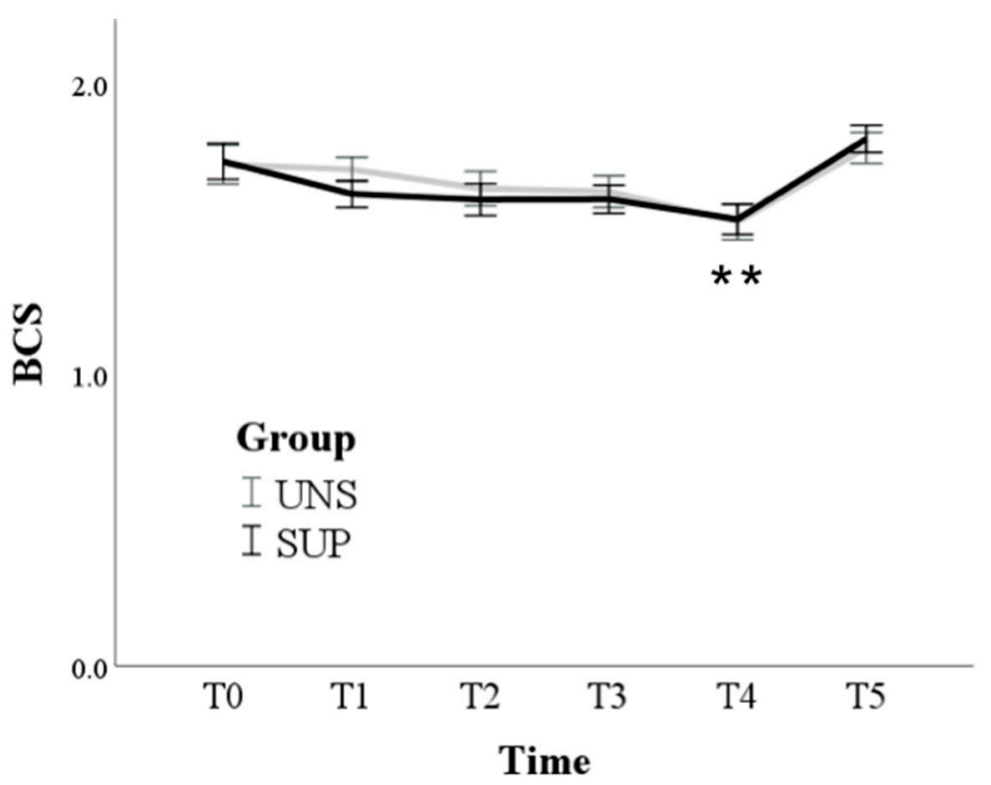

Figure 1. Means and standard errors of body condition score (BCS) in control (UNS) and supplemented (SUP) lactating sheep monitored before the administration of supplementation (T0), and then every 10 days until dry off (T1-T5). ** $p<0.01$ T4 vs. T0 in SUP and UNS.

Due to the high variability of the NES1 concentrations (mean $\pm \mathrm{SE}=121.96 \pm$ $29.09 \mathrm{pg} / \mathrm{mL} ; \mathrm{Mdn}(\mathrm{IQR})=15.86 \mathrm{pg} / \mathrm{mL}(10.00-65.68 \mathrm{pg} / \mathrm{mL}) ;$ range $=10.00-1000.00$ $\mathrm{pg} / \mathrm{mL}$ ), we decided to categorize these data according to their median value. Thus, two categories were created for NES1: "low level" if NES1 $<15.86 \mathrm{pg} / \mathrm{mL}$ and "high level" if NES1 $\geq 15.86 \mathrm{pg} / \mathrm{mL}$. No change over time was found for this binary variable $(p=0.949)$, while a significant effect of group was found $(p=0.033)$. Indeed, a higher percentage of NES1 samples from the UNS group were included in the high-level category compared to the SUP group $(60.2 \pm 7.7 \%$ and $36.1 \pm 7.7 \%$ of samples included in the high-level for UNS and SUP groups, respectively) (Figure 2). Mean values, standard error, and median with an interquartile range for NES1 concentrations in UNS and SUP groups are shown in Table S1.

The insulin log values increased during T2-T4 times compared to T0 $(p<0.001)$ (Figure 3 ) in both groups ( $p=0.795)$.

Glucagon levels were not affected by either time $(p=0.331)$ or group $(p=0.229)$ (Figure 4).

Overall, leptin levels increased from a marginal mean of $5.1 \pm 0.4 \mathrm{ng} / \mathrm{mL}$ at $\mathrm{T} 0$ to $5.8 \pm 0.4 \mathrm{ng} / \mathrm{mL}$ at T5 $(p=0.016)$. A significant group $\mathrm{x}$ time effect was also found $(p=0.028)$. Indeed, pairwise comparisons revealed that there were no significant changes over time in the UNS group $(p=0.252)$, while the SUP group showed a progressive increase from $\mathrm{T} 2$ to the last time point $(p=0.002)$ (Figure 5). 


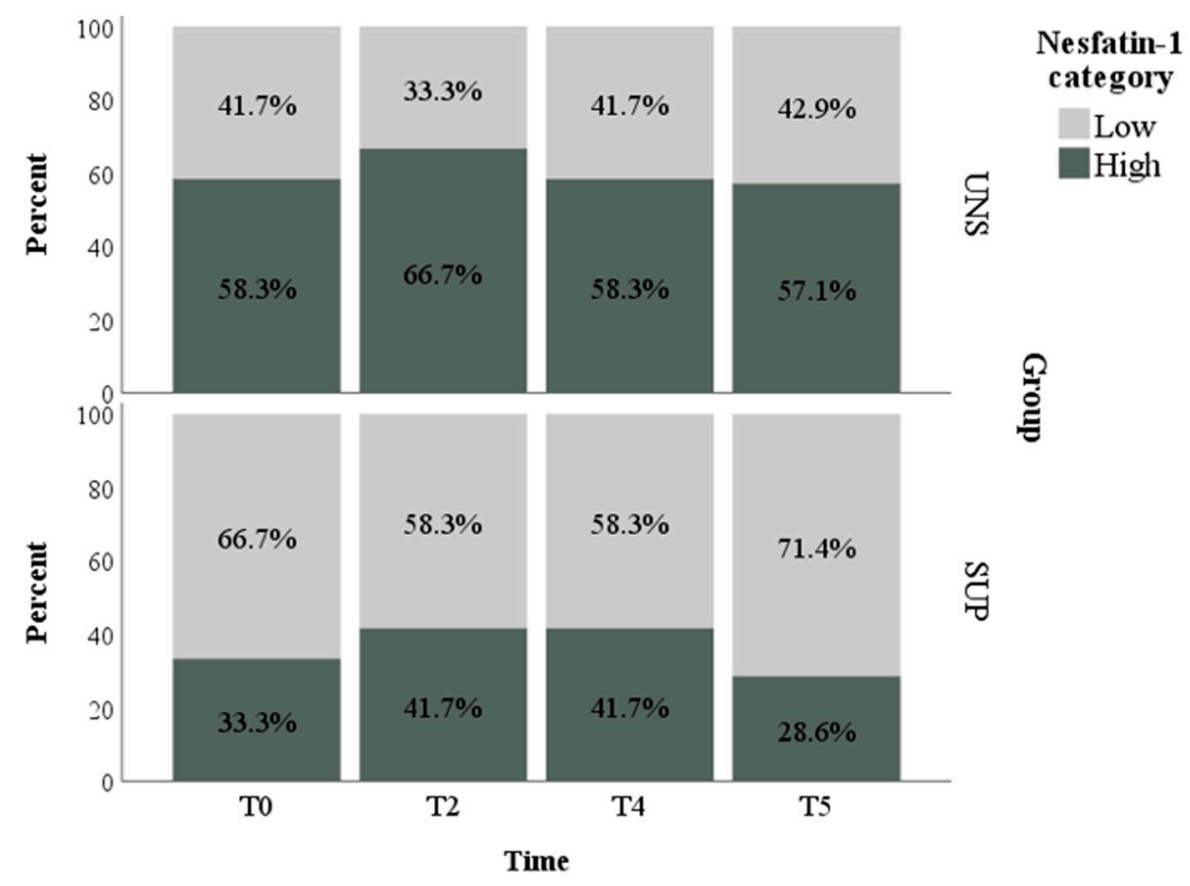

Figure 2. Relative frequencies of Nesfatin-1 categorized into "low" and "high levels" according to group $(\mathrm{UNS}=$ control ewes, $\mathrm{SUP}=$ supplemented ewes $)$ and time $(\mathrm{T} 0=$ before the administration of supplementation; $\mathrm{T} 2=20$ th day of supplementation; $\mathrm{T} 4=40$ th day of supplementation; T5 $=50$ th day of supplementation).

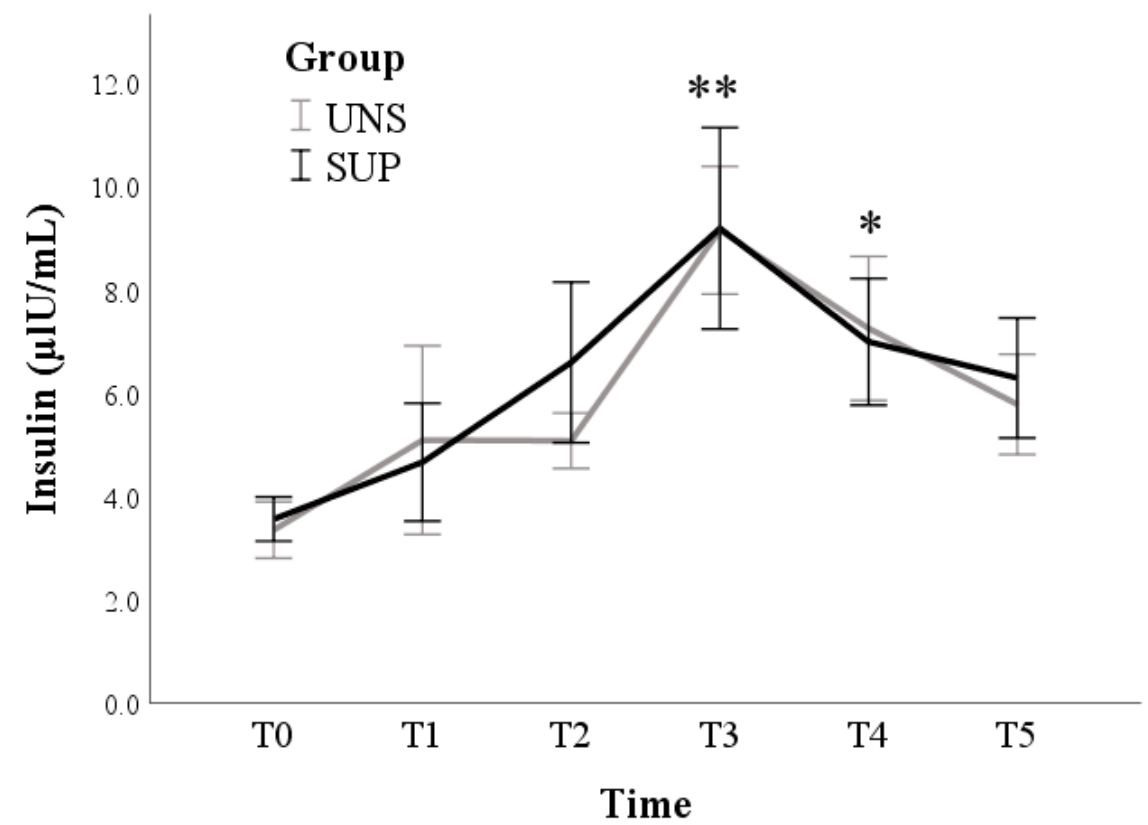

Figure 3. Means and standard errors of insulin plasma concentrations in control (UNS) and supplemented (SUP) lactating sheep monitored before the administration of supplementation (T0), and then every 10 days until dry off (T1-T5). ${ }^{*} p<0.05,{ }^{* *} p<0.01$ : each time vs. T0 in SUP and UNS. 


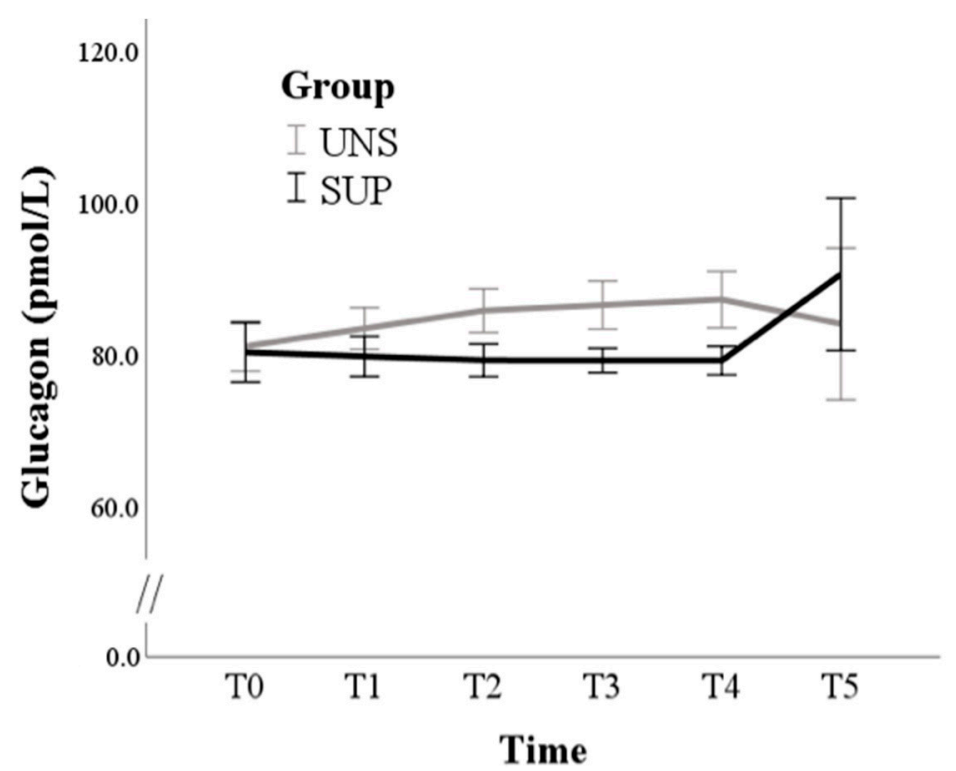

Figure 4. Means and standard errors of glucagon plasma concentrations in control (UNS) and supplemented (SUP) lactating sheep monitored before the administration of supplementation (T0), and then every 10 days until dry off (T1-T5).

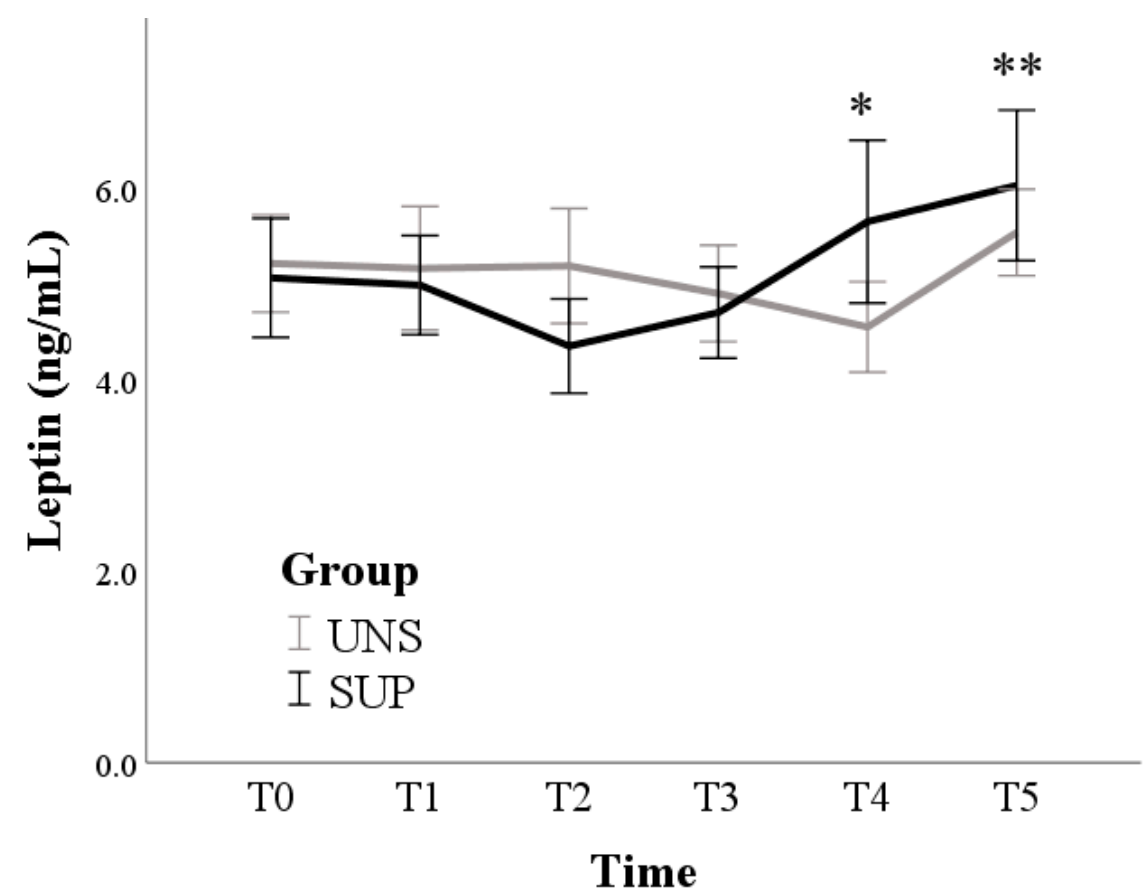

Figure 5. Means and standard errors of leptin plasma concentrations in control (UNS) and supplemented (SUP) lactating sheep monitored before the administration of supplementation (T0), and then every 10 days until dry off (T1-T5). ${ }^{*} p<0.05,{ }^{* *} p<0.01$ : each time vs. T0 in SUP.

TH concentrations reduced after 10 days (from $3.2 \pm 0.1 \mathrm{nmol} / \mathrm{L}$ at T0 to $2.8 \pm 0.1$ at $\mathrm{T} 1 ; p<0.001)$ but subsequently stabilized without differences between groups $(p=0.491)$ (Figure 6). 


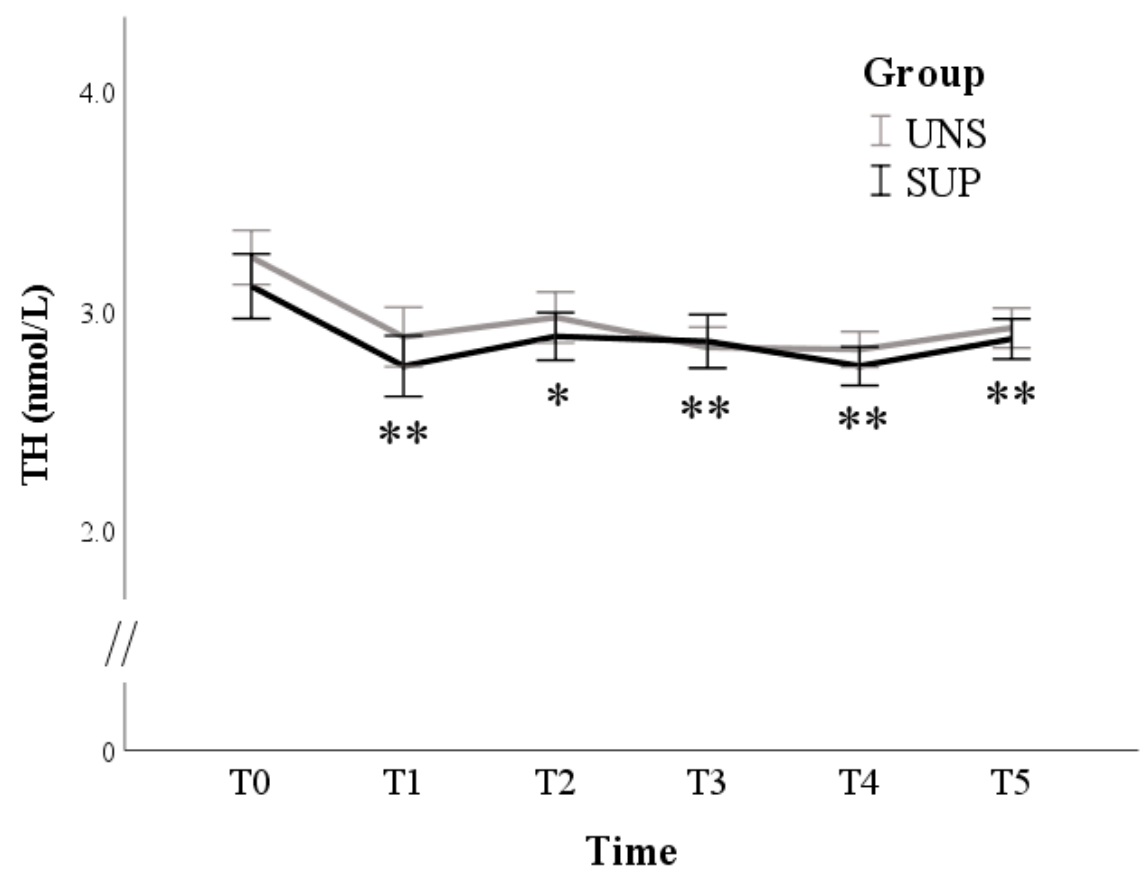

Figure 6. Means and standard errors of 3-3'-5-triiodothyronine (TH) plasma concentrations in control (UNS) and supplemented (SUP) lactating sheep monitored before the administration of supplementation (T0), and then every 10 days until dry off (T1-T5). ${ }^{*} p<0.05,{ }^{* *} p<0.01$ : each time vs. T0 in SUP and UNS.

Nutrition treatment affected the trend of cortisol: changes over time were not significant in the UNS group $(p=0.111)$, while the SUP group showed higher values than UNS at T0 $(p=0.033)$, followed by a significant reduction compared to T0 from T2 until T4 $(p<0.01)$ (Figure 7).

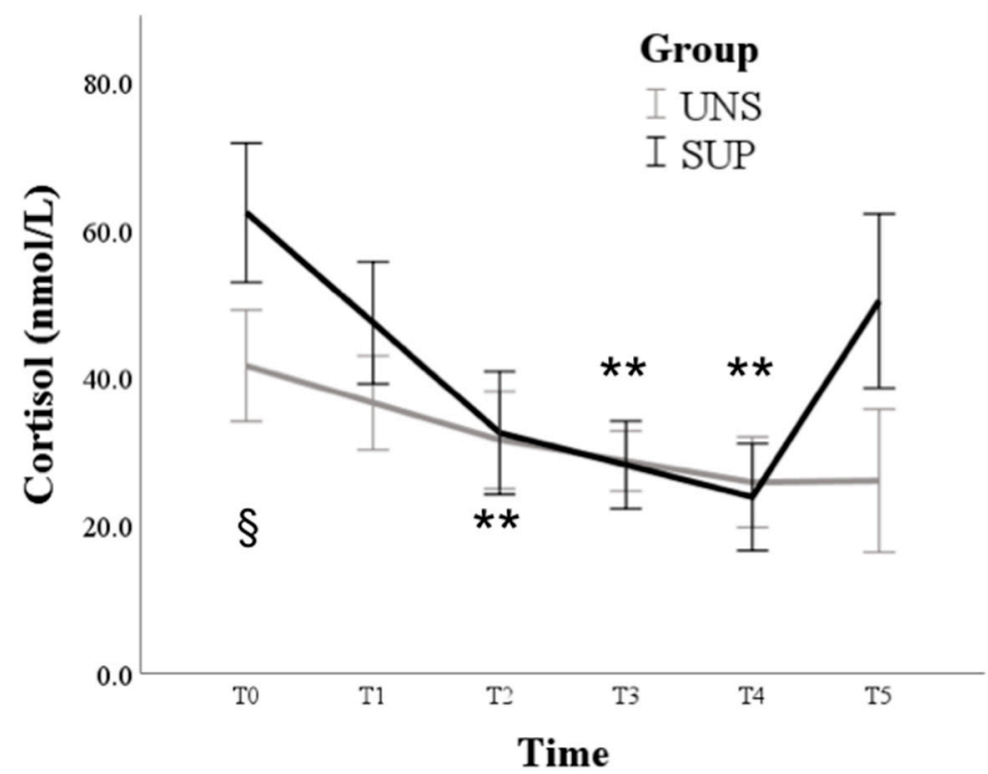

Figure 7. Means and standard errors of cortisol plasma concentrations in control (UNS) and supplemented (SUP) lactating sheep monitored before the administration of supplementation (T0) and then every 10 days until dry off (T1-T5). § $p<0.05$ UNS vs. SUP; ${ }^{* *} p<0.01$ vs. T0 in SUP. 


\subsection{Multivariable Approach}

Seven variables were included in the DA describing the body condition and hormonal profile of the ewes. One item was eliminated because it was identified as a multivariate outlier by the Mahalanobis distance. The variables that most discriminated the two groups were BCS and NES1 ( $p$-value < 0.05) (Table 1). The discriminant loadings (negative for BCS and positive for NES1) (Table 1) and centroids ( 0.666 and -0.610 for UNS and SUP, respectively) showed that lower BCS and higher NES1 characterized the UNS group compared to the SUP one. Overall, the DA showed a moderate discriminating ability: the model Wilks' Lambda was significant at $p<0.05$ level $(p=0.045)$ and the extracted discriminant function correctly classified $63.0 \%$ of the samples (cross-validation procedure).

Table 1. Parameters indicating the relative importance of variables in classifying the ewes receiving nutritional supplementation: discriminant loadings, Wilks' Lambda, and significance of the F test ( $p$-value). The variables with a significant F-test are in bold.

\begin{tabular}{cccc}
\hline Variable & Discriminant Loadings & Wilks' Lambda & $p$ Value \\
\hline BCS & -0.566 & 0.880 & $\mathbf{0 . 0 1 8}$ \\
Nesfatin-1 & 0.515 & 0.899 & $\mathbf{0 . 0 3 1}$ \\
Cortisol & -0.249 & 0.974 & 0.288 \\
TH & 0.126 & 0.993 & 0.588 \\
Insulin \# & 0.078 & 0.997 & 0.737 \\
Leptin & 0.042 & 0.999 & 0.857 \\
Glucagon & 0.037 & 0.999 & 0.875 \\
\hline
\end{tabular}

* included as continuous variable; \# included after log-transformation.

\section{Discussion}

The two ewes groups observed in the present study show very similar changes of the mean BCS value while, considering the univariable model analysis, no significant differences in the BCS changes and hormonal profiles between the two groups were noted.

These findings can be considered in relation to the milk production of the groups, which shows a clear better persistence in the SUP group, as reported in another paper by the same research project [28]. Milk yield was considered as relatively equal on day T0, while it was $78 \%$ vs. $45 \%$ at day 14 and $63 \%$ vs. $42 \%$ at day 33, in SUP and UNS, respectively. This observation can drive the hypothesis that the supplementation has protected the ewes from the usual lowering of the body state linked to the lactation, because it could be expected, on the contrary, that a higher and persistent milk production induces a more intense body reserve consumption. Indeed, the different hormones change with very scarce differences between the two groups and without any significant relationships with the body state (except NES1).

The multivariable analysis offers a more overall view of the changes in the considered parameters, weighing up the different effects and influences. In our analysis, the relationship between BCS and NES1 indicates the high probability that a better BCS level, as found in the SUP group, is related to a lower NES1 hematic concentration. This finding confirms that the nutritional supplementation had an effect on the body status, balancing the higher milk production in respect to the UNS group, and that these ewes, probably as a consequence of the nutritional supplementation, maintained a hunger motivation higher than the UNS: the lower blood Nesfatin-1 concentrations drive to suppose a higher hunger sense.

Regarding the changes of the other hormone concentrations, which can be of some interest in sheep grazing in our conditions, we can observe that concentrate supplementation significantly sustained milk production [28], which is often without affecting systemic concentrations of the hormones investigated. Therefore, in such conditions, the larger availability of nutrients in SUP ewes seems addressed toward milk synthesis by adaptations mostly driven at the peripheral (local) level [27]. 
Insulin participates in sustaining a general anabolic state during pregnancy, while the decrease in INS secretion and/or tissue responsiveness at the beginning of lactation allows the catabolic processes to dominate, and most of the nutrients are shifted toward the mammary gland for milk synthesis. The variations of INS concentrations observed over time in our study well agree with previous findings: an increase in plasma INS concentration has been widely described as lactation progresses, with decreasing milk yield and increasing energy balance [33,34]. The lowest concentrations of INS were found in ewes in early lactation (20 days); thereafter, plasma insulin significantly increased with the advancing stages of lactation (40 and 60 days) [35].

In our trial, glucagon changes were very scarce, and no significant difference was detected between groups. We can speculate that the slight increases in SUP opposite to the slight decrease in UNS can be consistent with a tendency to increase the available energy by its effects on hepatic glucose output and, possibly, lipolysis by adipose tissue.

In the SUP group, LEP concentrations progressively increase after two weeks of supplementation toward the end of lactation (T4) and dry off (T5). Similar to our results of the SUP group, in the ewe, leptinemia is reported to be very low during the first 3 weeks of lactation [36,37]; then, it gradually increases until about 3 months after lambing [38]. The lack of LEP increase with advancing lactation in UNS ewes likely mirrors the lack of improvements of the energy balance in these animals.

The plasma TH concentrations in both groups of ewes significantly lowered at day 85 of lactation, accordingly with previous reports. Thyroid hormone concentrations tended to decrease from $36 \mathrm{~h}$ to 21 days post-partum and thereafter constantly rose until day 51 postpartum [39], and slightly higher concentrations of TH were observed in the blood of ewes at the 40th day of lactation than at the 20th day [40]. After the start of our trial, animals were also exposed to rising summer ambient temperatures, which exert a well-known depressive effect on thyroid gland activity and TH action [41] and are inversely correlated with plasma thyroid hormone levels [25-43]. In the present study, high ambient temperatures may have prevented the physiological recovery of thyroid hormone concentrations, which are often observed toward the end of lactation in small ruminants, in parallel with the reduction of milk production and the increase of energy balance. On the other hand, in early lactation, low TH, leptin and insulin levels can indicate an energy deficiency of ewes, even despite the concentrate supplementation. Blood metabolic hormones and BCS are very useful tools for the assessment of ewes' nutritional status in very demanding physiological states, such as late pregnancy and lactation [40-44].

COR changes over time were not significant in the UNS group, while the SUP one showed higher values than the UNS group at T0, which was followed by a significant reduction until T4. The higher COR values found in the SUP group at the first sampling are likely due to the very large physiological variations among individuals when hormone concentrations increase facing different situations. For example, the blood-sampling procedure itself in unaccustomed animals could have played a role. Relatively low COR levels during lactation are reported in goats [45]. Regarding the COR peak observed in SUP ewes at the last sampling, different papers report similar effects by heat stress in small ruminants [46,47]. The serum COR levels were the highest during summer [43-49] and positively correlated with ambient temperature, showing reverse trends and negative correlations with TH [42-50]. Moreover, during thermal stress, feed-restricted ewes [51] and rams [25] showed less increase in cortisol blood concentrations: therefore, if the nutritional deficit is added to thermal stress, the animals can adjust their response, avoiding the potential adverse effects of extreme cortisol action, as it could be the case of the UNS group of the present study.

The trial planning foresaw performing further controls, especially aimed to know how the ewes of both groups cope with the successive reproductive season, in the hypothesis that the SUP group could face this demanding phase of the productive cycle performing better than the UNS one. Unfortunately, just at the start of the sexual season, when the males were to be joined in the female flock, in Central Italy a powerful earthquake took 
place (two strong events at the end of August and at the end of October). The farm where our ewes were kept suffered a lot of damage, as well as the houses of the farmers, so it was not possible to carry on the intended further controls, and the overall situation after the earthquake could have direct and indirect effects influencing the results. Despite this accident, fortunately, we had the possibility to have some indication from research performed on other ewes of the same flock, which showed that the feed supplementation had a positive effect on resistin production in the sheep uterine glands [52] and in the apelinergic system expression in both mammary glands and female reproductive apparatus [27-54].

\section{Conclusions}

Our results, notwithstanding the lack of the possibility to perform all the forecasted controls, indicate that the nutritional supplementation of lactating ewes reared in semiextensive conditions on mid mountain rangelands can determine an overall body and metabolic state better than expected in milking animals approaching reproductive activity. Our findings were especially revealed by the combined observations of (a) the ability by the SUP ewes to maintain a BCS value similar to the UNS one, despite higher milk production, and (b) the lower blood levels of NES1 that suggest a better penchant to restore their body reserve in view to face the reproductive engagement. On the contrary, the UNS ewes, due to a higher level of the anorexigenic peptide NES1, could have more difficulties to recover a good nutritional status in view of the sexual activity.

The fact that the circulating levels of some of the studied hormones did not show differences between unsupplemented and supplemented ewes do not indicate necessarily that the supplementation could not had favorable localized effects at the peripheral level. Indeed, recent studies carried out on the same animal groups suggested that the feed supplementation had a positive effect on some adipokine expression in different organ tissues.

Supplementary Materials: The following are available online at https:/ /www.mdpi.com/2076-261 5/11/3/682/s1, Figure S1. Experimental trial scheme; Figure S2. Means and standard errors of milk production at morning milking (mL) in control (UNS) and supplemented (SUP) lactating sheep. Milk yield was recorded as manually collected milk by each animal; Table S1. Mean and standard error (SE), and median (Mdn) with interquartile range (IQR) of Nesfatin-1 concentrations in control (UNS) and supplemented ewe (SUP) ewe before the administration of supplementation (T0), and after 20 (T2), 40 (T4), and 50 (T5) days of supplementation.

Author Contributions: Conceptualization, P.S. and A.M.; Methodology and validation, O.B., L.T. and A.M.; Formal analysis, L.M.; Investigation, E.D.F. and O.B.; Data curation, O.B., E.D.F. and L.M.; Writing —original draft preparation, O.B., L.T. and A.M.; Writing—review and editing, E.D.F. and O.B.; Supervision, P.S. All authors have read and agreed to the published version of the manuscript.

Funding: This research was funded by the UNIVERSITY OF CAMERINO by the grant FAR 2014-15 assigned to Prof. Andrea Catorci.

Institutional Review Board Statement: The study was conducted according to the guidelines of the Declaration of Helsinki, and approved by the Ministry of Health (No. of approval 95/2018-PR).

Informed Consent Statement: Not applicable.

Data Availability Statement: Datasets used in the analyses are stored at the authors' home institution and will be provided upon request.

Acknowledgments: Authors wish to thank C. Canali for his technical assistance and the staff of Azienda Di Pietrantonio for collaboration in animal management.

Conflicts of Interest: The authors declare no conflict of interest.

\section{References}

1. Scocco, P.; Piermarteri, K.; Malfatti, A.; Tardella, F.M.; Catorci, A. Effects of summer rainfall variations on sheep body state and farming sustainability in sub-Mediterranean pastoral systems. Span. J. Agric. Res. 2016, 14, 1-4. [CrossRef] 
2. Scocco, P.; Piermarteri, K.; Malfatti, A.; Tardella, F.M.; Catorci, A. Increase of drought stress negatively affects the sustainability of extensive sheep farming in sub-Mediterranean climate. J. Arid. Environ. 2016, 128, 50-58. [CrossRef]

3. Scocco, P.; Mercati, F.; Tardella, F.M.; Catorci, A. Increase of forage dryness indices differentiated anatomical response in the sheep rumen compartment. Microsc. Res. Tech. 2016, 79, 738-743. [CrossRef] [PubMed]

4. Giorgi, F.; Lionello, P. Climate change projections for the Mediterranean region. Glob. Planet. Chang. 2008, 63, 90-104. [CrossRef]

5. Arzeni, A.; Storti, D. Le strategie per lo sviluppo rurale nelle Aree interne colpite dal sisma. Agriregionieuropa 2017, 51, 1-8.

6. Robinson, J.; Ashworth, C.; Ashfort, J.; Rooke, L.; McEvoy, T. Nutrition and fertility in ruminant livestock. Anim. Feed Sci. Technol. 2006, 126, 259-276. [CrossRef]

7. Dore, R.; Levata, L.; Lehnert, H.; Schulz, C. Nesfatin-1: Functions and physiology of a novel regulatory peptide. J. Endocrinol. 2017, 232, R45-R65. [CrossRef] [PubMed]

8. Goebel, M.; Stengel, A.; Wang, A.; Tachè, Y. Central nesfatin-1 reduces the nocturnal food intake in mice be reducing meal size and increasing inter-meal intervals. Peptides 2011, 32, 36-43. [CrossRef]

9. Li, Z.; Gao, L.; Tang, H.; Yin, Y.; Zao, J.; Mulholland, M.; Zangh, W. Peripheral effects of nesfatin-1 on glucose homeostasis. PLoS ONE 2013, 8, e71513. [CrossRef]

10. Yoshida, N.; Maejima, Y.; Sedbazar, U.; Ando, A.; Kurita, H.; Damdinorj, B.; Takano, E.; Gantulga, D.; Iwasaki, Y.; Kurashina, T. Stressor-responsive central nesfatin-1 activates corticotropin-realising hormone, noradrenaline and serotonine neurons and evokes hipotalamic-pituitary-adrenal axis. Aging 2010, 2, 775-784. [CrossRef] [PubMed]

11. Vas, S.; Adori, C.; Konczol, K.; Katai, Z.; Pap, D.; Papp, R.S.; Bagdy, G.; Palkovitis, M.; Thot, Z.E. Nesfatin-1/NUCB2 as a potential new element of sleep regulation in rats. PLoS ONE 2013, 6, e59809. [CrossRef]

12. Gao, X.; Zhang, K.; Song, M.; Li, X.; Luo, L.; Tian, Y.; Zhang, Y.; Li, Y.; Zhangh, X.; Ling, Y. Role of nesfatin-1 in the reproductive axis of male rat. Sci. Rep. 2016, 6, 32877. [CrossRef] [PubMed]

13. Prajapati, G.N.; Kumar, A.; Laxmi, A.N.; Singh, N.K.; Mathur, A.K. Parallelism of nesfatin-1 and leptin with metabolic parameters and progesterone at puberty in Murrah buffalo heifers. J. Anim. Res. 2018, 7, 1-6.

14. Laarveld, B.; Christensen, D.A.; Brockman, R.P. The effect of insulin on net metabolism of glucose and amino acids by the bovine mammary gland. Endocrinology 1981, 108, 2217-2221. [CrossRef] [PubMed]

15. Todini, L.; Trabalza-Marinucci, M.; Malfatti, A.; Barbato, O.; Stradaioli, G.; Cavallucci, C.; Debenedetti, A. Pre- and post-feeding plasma Gastrin-17 and Insulin concentrations and feed intake in female goats during different physiological stages. Small Rumin. Res. 2007, 71, 38-47. [CrossRef]

16. Block, S.S.; Rhoads, R.P.; Bauman, D.E.; Ehrhardt, R.A.; McGuire, M.A.; Crooker, B.A.; Griinari, J.M.; Mackle, T.R.; Weber, W.J.; Amburgh, M.E.; et al. Demonstration of a role for insulin in the regulation of leptin in lactating dairy cows. J. Dairy Sci. 2003, 86, 3508-3515. [CrossRef]

17. Jiang, G.; Zhang, B.B. Glucagon and regulation of glucose metabolism. Am. J. Physiol. Metab. 2003, 284, E671-E678. [CrossRef]

18. Vaughan, M.; Steinberg, G.D. Effect of hormones on lipolysis and esterification of free fatty acid during incubation of adipose tissue in vitro. J. Lipid Res. 1963, 4, 193-199. [CrossRef]

19. Woods, S.C.; Lutz, T.A.; Geary, N.; Langhans, W. Pancreatic signals controlling food intake; Isulin, Glucagon and Amilyn. Philos. Trans. R. Soc. B Biol. Sci. 2006, 311, 1219-1235. [CrossRef]

20. Houseknecht, K.L.; Baile, C.A.; Matteri, R.L.; Spurlock, M.E. The biology of leptin: A review. J. Anim. Sci. 1998, 76, 1405-1420. [CrossRef]

21. Krasnow, S.M.; Steiner, R.A. Physiological Mechanisms Integrating Metabolism and Reproduction. In Knobil and Neill's Physiology of Reproduction; Neill, J.D., Ed.; Academic Press: San Diego, CA, USA, 1998; pp. 2553-2626.

22. Blache, D.; Tellam, R.L.; Chagas, L.M.; Blackberry, M.A.; Vercoe, P.E.; Martin, G.B. Level of nutrition affects leptin concentrations in plasma and cerebrospinal fluid in sheep. J. Endocrinol. 2000, 165, 625-637. [CrossRef] [PubMed]

23. Laud, K.; Gourdou, I.; Belair, L.; Keisler, D.H.; Djiane, J. Detection and regulation of leptin receptor mRNA in ovine mammary epithelial cells during pregnancy and lactation. FEBS Lett. 1999, 463, 194-198. [CrossRef]

24. Todini, L. Thyroid hormones in small ruminants: Effects of endogenous, environmental and nutritional factors. Animal 2007, 1, 997-1008. [CrossRef]

25. Maurya, V.P.; Sejian, V.; Kumar, D.; Naqvi, S.M.K. Impact of heat stress, nutritional stress and their combinations on the adaptive capability of Malpura sheep under hot semi-arid tropical environment. J. Anim. Behav. Biometeorol. 2019, 7, 31-38.

26. Caldeira, R.M.; Belo, A.T.; Santos, C.C.; Vazques, M.I.; Portugal, A.V. The effect of long-term feed restriction and over-nutrition on body condition score, blood metabolites and hormonal profiles in ewes. Small Rumin. Res. 2007, 68, 242-255. [CrossRef]

27. Mercati, F.; Maranesi, M.; Dall'Aglio, C.; Petrucci, L.; Pasquariello, R.; Tardella, F.M.; de Felice, E.; Scocco, P. Apelin System in Mammary Gland of Sheep Reared in Semi-Natural Pastures of the Central Apennines. Animals 2018, 8, 223. [CrossRef] [PubMed]

28. Scocco, P.; Rivaroli, S.; Mercati, F.; Tardella, F.M.; Malfatti, A.; de Felice, E.; Catorci, A. Anatomy for economy: Starting from the rumen keratinization degree to enhance the farm income. Econ. Agro Aliment. 2018, 20, 261-272. [CrossRef]

29. Scocco, P.; Mercati, F.; Brusaferro, A.; Ceccarelli, P.; Belardinelli, C.; Malfatti, A. Keratinization degree of rumen epithelium and body condition score in sheep grazing on Brachipodium rupestre. Vet. Ital. 2013, 49, 211-217.

30. Altman, D.G.; Bland, J.J. Uncertainty and sampling error. BMJ 2014, 349, g7064. [CrossRef]

31. Garson, G.D. Discriminant Function Analysis; Blue Book; Statistical Associates Publishers: Asheboro, NC, USA, 2012. 
32. Agradi, S.; Curone, G.; Negroni, D.; Vigo, D.; Brecchia, G.; Bronzo, V.; Chiesa, L.; Peric, T.; Danes, D.; Menchetti, L. Determination of fatty acids profile in original brown cows dairy products and relationship with alpine pasture farming system. Animals 2020, 10, 1231. [CrossRef]

33. Herbein, J.H.; Aiello, R.J.; Eckler, L.I.; Pearson, R.E.; Akers, R.M. Glucagon, Insulin, Growth Hormone, and Glucose Concentrations in Blood Plasma of Lactating Dairy Cows. J. Dairy Sci. 1985, 68, 320-325. [CrossRef]

34. Brockman, R.P.; Laarveld, B. Hormonal regulation of metabolism in ruminants: A review. Livest. Prod. Sci. 1986, 14, 313-334. [CrossRef]

35. Antunovic, Z.; Novoselec, J.; Sauerwein, H.; Speranda, M.; Vegara, M.; Pavic, V. Blood metabolic profile and some of hormones concentration in ewes during different physiological status. Bulg. J. Agric. Sci. 2011, 17, 687-695.

36. Ehrhardt, R.A.; Slepetis, R.M.; Bell, A.W.; Boisclair, Y.R. Maternal leptin is elevated during pregnancy in sheep. Domest. Anim. Endocrinol. 2001, 21, 85-96. [CrossRef]

37. Sorensen, A.; Adam, C.L.; Findlay, P.A.; Marie, M.; Thomas, L.; Travers, M.T.; Vernon, R.G. Leptin secretion and hypothalamic neuropeptide and receptor gene expression in sheep. Am. J. Physiol. Integr. Comp. Physiol. 2002, 282, R1227-R1235. [CrossRef] [PubMed]

38. González-García, E.; Tesniere, A.; Camous, S.; Bocquier, F.; Barillet, F.; Hassoun, P. The effects of parity, litter size, physiological state, and milking frequency on the metabolic profile of Lacaune dairy ewes. Domest. Anim. Endocrinol. 2015, 50, 32-44. [CrossRef] [PubMed]

39. Bekeova, E.; Elecko, J.; Krajnicakova, M.; Hendrichovsky, V.; Maracek, I. Dynamics of changes in concentrations of cholesterol and thyroid and ovarian hormones in blood-serum during postparturient period of ewes. Vet. Med. UVTIZ CSFR 1991, 36, 673-684.

40. Antunović, Z.; Novoselec, J.; Speranda, M.; Vegara, M.; Pavić, V.; Mioč, B.; Djidara, M. Changes in biochemical and hematological parameters and metabolic hormones in Tsigai ewes blood in the first third of lactation. Arch. Anim. Breed. 2011, 4, 535-545. [CrossRef]

41. Todini, L.; Malfatti, A.; Valbonesi, A.; Trabalza-Marinucci, M.; Debenedetti, A. Plasma total T3 and T4 concentrations in goats at different physiological stages, as affected by the energy intake. Small Rumin. Res. 2007, 68, 285-290. [CrossRef]

42. Da Silva, W.E.; Leite, J.H.G.M.; da Silva, W.S.T.; Paiva, R.D.M.; de Sousa, J.E.R.; Facanha, D.A.E. Seasonal variations in thermoregulatory patterns enable Morada Nova sheep to adapt to Brazilian semi-arid. Semin. Agrar. Sci. 2019, 40, 1577-1594. [CrossRef]

43. Rathwa, S.D.; Vasava, A.A.; Pathan, M.M.; Madhira, S.P.; Patel, Y.G.; Pande, A.M. Effect of season on physiological, biochemical, hormonal, and oxidative stress parameters of indigenous sheep. Vet. World 2017, 10, 650-654. [CrossRef]

44. Menchetti, L.; Curone, G.; Andoni, E.; Barbato, O.; Troisi, A.; Fioretti, B.; Polisca, A.; Codini, M.; Canali, C.; Vigo, D.; et al. Impact of Goji Berries (Lycium barbarum) Supplementation on the Energy Homeostasis of Rabbit Does: Uni- and Multivariate Approach. Animals 2020, 10, 2000. [CrossRef]

45. Gupta, V.K.; Sharma, S.D.; Vihan, V.S.; Kumar, A. Serum enzymes and thyroid hormone in sub-clinical ketosis in goats and sheep reared under organized farming system. Ind. J. Anim. Sci. 2008, 78, 1199-1201.

46. Ribeiro, M.N.; Ribeiro, N.L.; Bozzi, R.; Costa, R.G. Physiological and biochemical blood variables of goats subjected to heat stress-A review. J. Appl. Anim. Res. 2008, 46, 1036-1041. [CrossRef]

47. Maurya, V.P.; Sejian, V.; Kumar, D.; Naqvi, S.M.K. Biological ability of Malpura rams to counter heat stress challenges and its consequences on production performance in a semi-arid tropical environment. Biol. Rhythm. Res. 2018, 49, 479-493. [CrossRef]

48. Inbaraj, S.; Kundu, A.; De, A.K.; Sunder, J.; Sejian, V. Seasonal changes in blood biochemical and endocrine responses of different indigenous goat breeds of tropical island agro-ecological environment. Biol. Rhythm. Res. 2018, 49, 412-421. [CrossRef]

49. Yilmaz, M.; Altin, T.; Kiral, F.; Taskin, T.; Asici, G.S.E.; Kizilkaya, K. Effects of the season on physiological and endocrine traits and on HSP70 in Saanen goats under Mediterranean climate conditions. Med. Weter. 2018, 74, 39-47. [CrossRef]

50. Sejian, V.; Indu, S.; Naqvi, S.M.K. Impact of short term exposure to different environmental temperature on the blood biochemical and endocrine responses of Malpura ewes under semi-arid tropical environment. Ind. J. Anim. Sci. 2013, 83, 1155-1159.

51. Sejian, V.; Maurya, V.P.; Naqvi, S.M.K. Adaptive capability as indicated by endocrine and biochemical responses of Malpura ewes subjected to combined stresses (thermal and nutritional) in a semi-arid tropical environment. Int. J. Biometeorol. 2010, 54, 653-661. [CrossRef]

52. Dall'Aglio, C.; Scocco, P.; Maranesi, M.; Petrucci, L.; Acuti, G.; de Felice, E.; Mercati, F. Immunohistochemical identification of resistin in the uterus of ewes subjected to different diets: Preliminary results. Eur. J. Histochem. 2019, 63, 127-130. [CrossRef] [PubMed]

53. Mercati, F.; Scocco, P.; Maranesi, M.; Acuti, G.; Petrucci, L.; Cocci, P.; Renzi, A.; de Felice, E.; Dall'Aglio, C. Apelin system detection in the reproductive apparatus of ewes grazing on semi-natural pasture. Theriogenology 2019, 139, 156-166. [CrossRef]

54. Scocco, P.; Mercati, F.; Catorci, A.; Maranesi, M.; Acuti, G.; de Felice, E.; Petrucci, L.; Dall’Aglio, C. Histochemistry as supporting tool in grassland ecosystem management: Apelin system detection in ewe reproductive apparatus. Eur. J. Histochem. 2019, 63, 31. 